\title{
A new era of European Integration? \\ Governance of Labour market and social policy since the Sovereign debt crisis de la Porte, Caroline; Heins, Elke
}

Published in:

Comparative European Politics

DOI:

10.1057/cep.2014.39

Publication date:

2015

Citation for published version (APA):

de la Porte, C., \& Heins, E. (2015). A new era of European Integration? Governance of Labour market and social policy since the Sovereign debt crisis. Comparative European Politics, 13(1), 8-28.

https://doi.org/10.1057/cep.2014.39

\section{General rights}

Copyright and moral rights for the publications made accessible in the public portal are retained by the authors and/or other copyright owners and it is a condition of accessing publications that users recognise and abide by the legal requirements associated with these rights.

- Users may download and print one copy of any publication from the public portal for the purpose of private study or research.

- You may not further distribute the material or use it for any profit-making activity or commercial gain.

- You may freely distribute the URL identifying the publication in the public portal.

Take down policy

If you believe that this document breaches copyright please contact rucforsk@kb.dk providing details, and we will remove access to the work immediately and investigate your claim. 


\title{
Original Article
}

\section{A new era of European Integration? Governance of labour market and social policy since the sovereign debt crisis}

\author{
Caroline de la Porte ${ }^{\mathrm{a}, *}$ and Elke Heins ${ }^{\mathrm{b}}$ \\ ${ }^{a}$ Department of Society and Globalisation, Roskilde University, Universitetsvej 1, Roskilde 4000, \\ Denmark. \\ E-mail: cporte@ @uc.dk \\ ${ }^{\mathrm{b}}$ School of Social and Political Science, University of Edinburgh, 15A George Square, \\ Edinburgh EH8 9LD, UK. \\ E-mail: elke.heins@ed.ac.uk \\ *Corresponding author.
}

\begin{abstract}
In this article we develop a typology of European Union (EU) integration to capture how, to what extent and according to which policy aims EU involvement in Member States has altered with respect to labour market and social policy and what it signifies in terms of institutional change. On this basis, we show first that new instruments - the Six-Pack, Fiscal Compact and Two-Pack - have been layered onto the existing institutional framework governing the Economic and Monetary Union (EMU). Furthermore, we show that the instruments strengthening budgetary discipline to improve the functioning of European Monetary Union have become more explicit in terms of policy objectives, particularly specifying new benchmarks to obtain fiscal discipline. They are also stricter in terms of surveillance and enforcement. Second, we show that there are initiatives to address and improve the social dimension of the EU Europe 2020, the Social Investment Package and the Youth Guarantee - and that these have also emerged through a process of institutional layering. However, the aims around Europe 2020 and Social Investment continue to be based on the voluntary Open Method of Coordination, with comparatively weak surveillance and enforcement. In the current context, and in order to attain economic growth together with social cohesion and welfare, it is of utmost importance that EMU criteria should be altered to take account of social investments.
\end{abstract}

Comparative European Politics advance online publication, 29 September 2014; doi:10.1057/cep.2014.39

Keywords: European Integration; institutional change; governance; stability and growth pact; European social policy 


\section{Introduction: The European Union (EU) and Social Policy}

The EU aims to safeguard and promote high social standards across the EU, but respecting welfare state diversity (Scharpf, 2002). Since the Economic and Monetary Union (EMU) was institutionalised in 1992, the EU intervenes indirectly - as a functional spill-over from monetary integration - in social and fiscal policy. In 1997, the Stability and Growth Pact (SGP) - a process of policy coordination with EU benchmarks and policies, national reports and EU surveillance as well as corrective mechanisms in case of deviation from these aims - was developed to ensure compliance with EMU aims. Most important in this initial institutional architecture are the limits for public debt (maximum 60 per cent of GDP) and budget deficits (maximum 3 per cent of GDP). As social spending makes up the biggest share of public expenditure in Member States (more than half of total government expenditure was devoted to the functions 'social protection' and 'health' between 2002 and 2012 according to Eurostat figures), the pressure on national welfare states exerted by the SGP is therefore considerable, especially during economic recessions.

The core actors involved in EMU governance are economically oriented, that is DG ECFIN, and the Council for Economic and Financial Affairs as well as the European Central Bank. These actors are all concerned with upholding the monetarist paradigm, and with it supply-side policies, such as labour market de-regulation as well as cost containment in areas such as pensions and health care (Scharpf, 2011; Barbier, 2012; de la Porte and Pochet, 2014). The SGP and the monetarist paradigm that underpins it, has not been without criticism. McNamara (2005, p. 156) notes, "Although the SGP has the word "growth" in its title, it is not likely to promote growth, but rather to be excessively restrictive at precisely the times that European states may need to stimulate their economies, as states are more likely to run up deficits in economic recessions'.

In the mid-1990s and as a response to the EMU and the functional spill-overs on (pressure to decrease) social expenditure, the development of a 'social dimension' to the EU was seen as indispensable by left-of-centre political actors. The notion of a 'European Social Model' represents the idea that European welfare states are legitimately diverse, but that they all aim to uphold high social standards, working conditions and well-being, which should be supported by the EU (Jepsen and Serrano Pascual, 2005). In core welfare state areas, where Member States face similar challenges, such as unemployment, ageing populations and new social risks, the EU has promoted various ideas, for example, 'flexicurity' (Viebrock and Clasen, 2009), 'active ageing' or a 'lifecourse' approach to labour market participation - facilitating breaks from the labour market for education, parenting and care responsibilities without potential loss of job.

These policy ideas, many of them central in the emerging 'social investment' paradigm (Morel et al, 2012) have been promoted through the European Employment Strategy (EES) and the Open Method of Coordination (OMC), thereby 
contributing to the development of the 'European Social Model', although only through voluntary policy coordination. These policies have been promoted by 'socially oriented actors', that is, DG Employment and Social Affairs and the Employment and Social Affairs Council. Compared with the 'economically oriented actors' they have a weak legal basis for influencing welfare state reforms. Indeed, all decisions about the organisation, financing and delivery of social security have thus far remained at national level. While some countries have adopted common EU policy ideas through the OMC, its overall impact on welfare reforms has been weak (de la Porte and Pochet, 2012).

However, even the Treaty-based and thus much more enforceable SGP had its limitations. In the asymmetrical architecture of the EMU, monetary policy is pooled at EU level, while fiscal policy remains uncomfortably caught between EU and national level through EU pressure to curb public finances, but without direct or formal EU competency in this area (Scharpf, 2002; McNamara, 2005). While some Member States did undertake substantial reforms to comply with the Maastricht criteria before the 2007 financial crisis (see, for example, Hassenteufel et al, 2000; Jessoula, 2012), the SGP was not sufficient to keep all countries within the set limits (De Haan et al, 2004; McNamara, 2005). When the 2007 global financial crisis laid bare the asymmetries within the Eurozone and problems with the SGP's enforcement, this led to an incremental alteration of instruments and policies that affect welfare state reform, both indirectly, via the architecture of the EMU, especially regarding fiscal policy, and directly, aiming to affect welfare policy per se.

In this article, we analyse how the instruments developed in response to the crisis have altered the existing EU institutional framework with regard to labour market and social policy. In the next section, we develop the analytical framework, consisting first of a typology for detecting changes in EU integration and involvement and second, of a clarification of concepts to analyse institutional change. In the subsequent section, we analyse how new instruments have been developed since the onset of the crisis that affect the EMU and the social dimension. First, we analyse the development of instruments in the governance of fiscal and budgetary policy. We find that they have become more precise in terms of objectives, and stricter in terms of surveillance and enforcement, and that new instruments have been grafted onto existing institutional frameworks through a process of layering. Thereafter, we analyse the development of instruments more directly aimed at social and labour market policy. The findings show that the new initiatives have been layered onto the existing foundation in Europe 2020, but that they are weak in terms of surveillance and enforcement. This signifies that their potential impact is weak compared with the instruments governing policy via the EMU. In the penultimate section, we analyse the implications of the findings for European social policy. Overall, we find that the alteration of the EMU governance framework with its pressure on fiscal consolidation, and as a side-kick the Social investment strategy developed in a weaker framework, penetrate deeper into welfare state policies than 
before the crisis. Finally, in the conclusion, we discuss the significance of the new EU governance instruments for welfare states and the process of European Integration.

\section{Analytical Framework for Analysing Alterations in EU Integration in Labour Market and Social Policy}

In this section, we develop a typology of 'EU integration' to analyse the main new instruments since the crisis and their significance for labour market and social policy along three dimensions: objectives (policy aims), surveillance process and mechanisms of enforcement. For each, there are four possible degrees of EU involvement (from low to very high). Furthermore, a transversal issue we consider is the balance of actors involved, in devising policy objectives, and in the surveillance and enforcement processes. We argue that including employment and social policy actors (or other issue-specific actors) within a policy process provides a more comprehensive approach, for example, considering economic but also social sustainability aims, compared with processes driven exclusively or mainly by actors in economic and financial affairs, which are more narrowly focused on aims of fiscal consolidation. Second, to render this analysis dynamic and longitudinal, we analyse how these instruments and policies have altered the EU institutional framework governing economic, labour market and social policy over time, with the use of four key concepts from the literature on incremental institutional change: layering refers to creating a new policy grafted onto an existing institutional framework; revision refers to the formal reform, replacement or elimination of existing policy; policy drift refers to the altered effect of a policy because of changed circumstances, and conversion refers to redirection of an existing policy framework for new purposes ${ }^{1}$ (Hacker, 2004).

The first dimension of integration is objectives (policy aims), that is, how precisely and to which magnitude policy change is suggested, which is a first indicator of the depth of EU involvement in Member States' social and employment policy, where EU competencies are marginal. We consider EU involvement as low if no change in objectives is required, but only minor changes to existing policies are suggested. Medium EU involvement would be indicated by more alterations, but without changing the institutional set-up. High (and very high) levels of involvement signify alterations with the potential for undermining the existing institutional structure and fundamental principles of a policy area, thus indicating a high amount of external pressure. Some objectives, such as adjusting the levels of pension benefits, would represent a medium level of EU involvement, as it does not signify new principles of organising pension policy, but just an alteration within an existing institutional set-up. A policy aim such as enhancing social sustainability of pension systems would imply low involvement unless this aim were accompanied by specific measures, while a policy aim suggesting reform of the existing pension system would signify high or very high EU involvement. In practice, and as we know from 
research on Europeanisation of welfare policies, any policy objective would have a differentiated effect in Member States depending on a wide range of issues in the domestic arena, such as ideas, politics and markets. For example, in familialistic welfare states the promotion of formal childcare policies (such as targets for the number of children in early childhood education) may be seen as high EU involvement because it challenges the existing male breadwinner/female carer model and demands a significant change in policy objectives. In the Nordic welfare states, by contrast, such a policy merely confirms or re-enforces the existing policy paradigm that supports the reconciliation of work with family life and EU involvement would thus be low. However, it is necessary to consider not only domestic factors and the institutional fit with EU policy objectives, but also which type of EU surveillance and enforcement they are exposed to.

The second dimension of EU involvement is thus the surveillance of national policy by EU actors, which addresses with which mechanism the EU is endowed to monitor whether Member States are implementing the agreed policies and moving towards EU benchmarks and/or national targets. The strength of surveillance is indicated by the frequency of policy monitoring and on whether the basis for surveillance is soft or hard law. It is also important to take account of which EU actors are involved in a particular surveillance process. Some EU actors, namely the economic and financial actors, operate in areas where the EU has strong jurisdiction so that these actors have more power than others, such as the employment and social affairs actors, where the EU has only weak legislative competence.

The third dimension of EU involvement is enforcement, referring to the type of measures EU actors have at their disposal to ensure implementation and/or corrective action in the case of non-compliance with or deviation from EU policy. The most coercive form consists of financial sanctions, although they have never been levied. Another form of enforcement consists of delineating a reform path and timetable to be followed in order to achieve an EU benchmark or aim in an 'excessive deficit procedure' (EDP) or 'country specific recommendation' (CSR). This may alter an institution in different ways depending on the specificity of objectives and how it fits with the existing institution. An EDP is Treaty-based and designed to ensure that a country effectively corrects a deficit, while a recommendation under an OMC is merely a suggestion for reform, with no consequences in the case of non-compliance. In assessing enforcement, it is important to take account of the power balance between European institutions and Member States. In particular, the requirement of a qualified majority vote (QMV) gives more leverage to Member States, since a qualified majority of Member States must agree to impose a sanction. By contrast, a reverse qualified majority voting (RQMV) gives more power to the European Commission, because a qualified majority of Member States would need to agree not to impose a sanction. Up to present, it is a mechanism that functions as a threat, as it has never been applied. A very high level of enforcement, combined with very strict surveillance, occurs in the case of countries that are under EU bail-out and have to 
subject themselves to rigorous conditionality as a consequence of loan receipt in Memorandums of Understanding (see Theodoropoulou, this issue). In such cases, very specific policy objectives, a very high degree of surveillance as well as enforcement, lead to 'intrusiveness' in domestic settings. This particular type of EU involvement would be captured by the last column of our typology (see Table 1).

\section{Analysing Governance of Social and Labour Market Policy since the Crisis}

This section begins with presenting the European Semester within which all new instruments are embedded and layered onto existing institutional foundations (see Figure 1).

The 'European Semester' is a cycle of economic and fiscal policy coordination within the EU, agreed in 2010 which aims to increase coherence and effectiveness of economic and social policies. It is launched yearly by the European Commission (2013c) via an 'Annual Growth Survey' (AGS) that assesses progress of the past year and sets out EU growth and job creation priorities for the coming year. ${ }^{2}$ The European Semester, and in particular the AGS, is very powerful for the agenda-setting process as it gathers all policy aims, instruments and actors involved in economic, social and labour market policy. Furthermore, it is used to forward proposals for further strengthening the institutional architecture of the EU (European Council, 2011).

\section{Altering the governance of EMU since 2010}

The Maastricht Treaty of 1992 introducing EMU-pooled monetary policy at EU level, while fiscal policy remained at national level. The 3 per cent budget deficit criterion was closely monitored and in the event of its breach by a Member State, an EDP could be launched. In the EDP, a plan was devised between the Member State and the Commission in order to exit the EDP, which could include reforms in pensions, health care or education. However, in 2005, this process was altered to take account of public investments. This rule change was controversial as it was put forward in the context on non-compliance with SGP criteria by France and Germany that pointed to a politicisation and thus weakening of the process. In essence, however, the initial institutional architecture was not altered. Before the financial crisis of 2008, surveillance and enforcement of the SGP was medium, while the policy aims were highly specified (de la Porte and Heins, 2014). After 2010, when the Euro was under threat, the EU instruments governing EMU and the oversight of Member States' budgets were reformed. The Six-Pack, the FC and the Two-Pack have altered the institutional framework radically, but through a process of institutional layering rather than a revision of the existing framework. 
Table 1: Typology of EU integration of labour market and social policy

Dimension of Degree of involvement

integration

Low Medium High

Very high

\begin{tabular}{|c|c|c|c|c|}
\hline $\begin{array}{l}\text { Objectives } \\
\text { (policy aims) } \\
\text { Note: This } \\
\text { may differ } \\
\text { according to } \\
\text { welfare state }\end{array}$ & $\begin{array}{l}\text { Uncontroversial objectives, } \\
\text { not challenging existent } \\
\text { institutional } \\
\text { arrangements, merely } \\
\text { suggesting some minor } \\
\text { adjustments in a particular }\end{array}$ & $\begin{array}{l}\text { Objectives challenging some } \\
\text { existing policies, but not the } \\
\text { underlying institutional } \\
\text { structure of a policy area }\end{array}$ & $\begin{array}{l}\text { Objectives requiring } \\
\text { comprehensive policy reform } \\
\text { with the potential for } \\
\text { undermining the existing } \\
\text { institutional structure and } \\
\text { fundamental principles of }\end{array}$ & $\begin{array}{l}\text { Objectives requiring far-reaching } \\
\text { structural reform with a high } \\
\text { potential for undermining the } \\
\text { existing institutional structure and } \\
\text { for changing the fundamental } \\
\text { principles of a policy area }\end{array}$ \\
\hline
\end{tabular}

type (and policy area

a policy area

policy area)

Surveillance Infrequent ex-post $\mathrm{EU}$ surveillance of national policy reports

Frequent ex-post surveillance of Regular ex-ante and ex-post EU national reports that specify surveillance of national policy (country-specific) policy reports. MS accountable to EU which should meet common benchmarks and/or own benchmarks or national targets and required to specify action national targets plan to meet these

Enforcement 'Naming and shaming' and/ Treaty-based recommendations, Treaty-based recommendations or soft recommendations and possibility for sanctions and quasi-automatic financial (with a weak Treaty base) in the case of non-compliance sanctions in the case of noncompliance

Frequent ex-ante and ex-post $\mathrm{EU}$ surveillance of national policy reports. MS accountable to their own policies (which must aim to meet European targets and/or policy)

Conditionality (specified structural reforms) in order to receive financial assistance 


\begin{tabular}{|c|c|c|c|}
\hline & $\begin{array}{l}\text { Instruments of fiscal } \\
\text { policy coordination }\end{array}$ & $\begin{array}{l}\text { Mutual } \\
\text { influence of the } \\
\text { two sets of } \\
\text { instruments }\end{array}$ & $\begin{array}{l}\text { Instruments of social and labour } \\
\text { market policy coordination }\end{array}$ \\
\hline \multirow{5}{*}{$\begin{array}{l}\text { Instruments } \\
\text { and core } \\
\text { objectives }\end{array}$} & Two-Pack 2013 & & \\
\hline & Fiscal Compact 2012 & & Youth Guarantee 2013 \\
\hline & Six-Pack 2011 & & Social Investment Package 2013 \\
\hline & Stability and Growth & & Euro-plus Pact 2011 \\
\hline & Pact1992 & & $\begin{array}{l}\text { Europe } 2020 \text { (previously Lisbon } \\
\text { Strategy, EES and social OMCs) } 2010\end{array}$ \\
\hline \multirow[t]{2}{*}{$\begin{array}{l}\text { Application } \\
\text { of EU cycle } \\
\text { Immediate } \\
\text { objectives }\end{array}$} & $\begin{array}{c}\text { MIP, MTOs } \\
\text { structural deficit rule, } \\
\text { debt-deficit rule } \\
\text { Convergence/Stability } \\
\text { Programmes, DBPs }\end{array}$ & & $\begin{array}{l}\text { NRP, National Youth Employment } \\
\text { Plans }\end{array}$ \\
\hline & \multicolumn{3}{|c|}{ Annual Growth Survey } \\
\hline $\begin{array}{l}\text { EU } \\
\text { enforcement } \\
\text { and } \\
\text { surveillance }\end{array}$ & $\begin{array}{l}\text { AMR, EDP, opinions on } \\
\text { DBPs }\end{array}$ & & $\begin{array}{l}\text { CSR, EPP commitments, Youth } \\
\text { Employment Initiative, co-funding } \\
\text { via ESF }\end{array}$ \\
\hline
\end{tabular}

Figure 1: Layering of instruments within the European Semester.

\section{Six-pack}

In December 2011, the 'Six-Pack' ${ }^{3}$ was adopted to increase the strength and scope of surveillance of all Member State economies with some specific rules for Eurozone Member States, especially regarding financial sanctions. The Six-Pack introduces several novelties that enhance European Integration regarding fiscal and macroeconomic policy in terms of precision of objectives, mechanisms of surveillance as well as enforcement.

First, with regard to specifying and monitoring fiscal consolidation, Member States' budget balance shall converge towards country-specific medium-term objectives (MTOs). Furthermore, country-specific structural balances are specified: they can range from a structural budget deficit of 1 per cent of GDP to a budget in surplus. These MTOs embody a high degree of surveillance compared with the situation before the crisis. The structural budget deficit is a new benchmark that has been added on to the original provisions in the Maastricht Treaty. The structural deficit, together with the 3 per cent budget deficit, is seen as more accurate than the budget deficit criterion alone as it aims to filter out temporary fiscal measures and 
evolutions that are because of cyclical changes in the economy (Verhelst, 2012). This preventative approach aims to keep Member State economies healthy in good times, rather than accumulating high deficits, and represents tighter integrated EU-Member State surveillance of budgets, by making them accountable to their own MTOs. Furthermore, enforcement is high: the Commission can issue a warning to a Member State in case of significant deviation from its own adjustment path defined in the MTO. National governments may thus have less leverage in defining (or rather differentiating) their national political agendas (including welfare state reforms), because of the MTO, and the structural budget deficit, which constrains their budgets and thus plans for expansive fiscal spending, such as in social and labour market policy (European Commission, 2013b).

A second novelty of the Six-Pack is the 'Macroeconomic Imbalance Procedure' (MIP) with accompanying indicators that is more far-ranging than the focus on public finances as under the original SGP. In 2012, 11 indicators were selected for a scoreboard by DG ECFIN for monitoring the health of Member States' economies, including private debt, nominal unit labour costs and unemployment. This tool has enhanced the surveillance capability of the European Commission towards Member States. Although the Commission will take account of country-specific circumstances, the scoreboard represents a tool to quantitatively assess national economies. It can lead to 'Alert Mechanism Reports' (AMR), that is, in-depth reviews suggesting corrective action to ensure the health of national economies. In the first AMR, 12 Member States were subject to in-depth review, while in the second, 14 Member States were subject to in-depth review (European Commission, 2012b).

Third, the Six-Pack increases enforcement of the SGP in case of non-compliance since an EDP can be launched if Member States have breached either the deficit or the debt criterion, where previously only the deficit criterion was operational. Concerning enforcement, an EDP is launched, like before the crisis, through QMV in the Council. The level of enforcement is therefore only medium in this respect. However, in contrast to the situation before the crisis, the punitive aspect of enforcement has become very high for countries not complying with the correction of the deficits or debts according to their plans. Indeed, if no effective action has been taken, quasi-automatic sanctions will be applied that could only be blocked by RQMV in the Council. This means that a qualified majority of Member States (in Ecofin) must be against a Commission (DG ECFIN) proposal for a sanction to be overturned (Van Aken and Artige, 2013). This represents a high level of enforcement. This measure is accompanied by a high degree of surveillance to verify that agreed measures to correct the imbalance are carried out.

In sum, fiscal consolidation objectives are highly specified and EU influence can be assessed as potentially high on this dimension as national governments have less leverage in defining (or rather differentiating) their national policy agendas (including welfare state reforms) because of the budget-restraining MTOs. The Six-Pack embodies a more tightened and thus high degree of integration on the surveillance 
dimension compared with the situation before the crisis as a broader range of the economy is considered in the surveillance of Member State budgets through the MIP. In addition, with the new structural budget deficit criteria a new benchmark has been added to the 3 per cent budget deficit criterion of the original Maastricht Treaty. Finally, the Six-Pack increases the enforcement of the SGP in case of noncompliance since an EDP can be launched if Member States have breached either the deficit or the debt criterion, where previously only the deficit criterion was decisive. The Six-Pack thus introduces benchmarks, mechanisms and processes through which to improve the plausibility of meeting the fiscal consolidation aims of the EMU and of preventing future crises. This has an indirect but strong spill-over on welfare policy, to which a large part of public expenditure is devoted.

\section{Fiscal Compact}

The Fiscal Compact, added in 2012, is another legislative initiative that strengthens the aim of fiscal consolidation, together with surveillance and enforcement measures. ${ }^{4}$ It complements and further reinforces the SGP by including an automatic correction mechanism in the case of significant deviations from the MTO or the adjustment path towards it and strengthens the automaticity of the EDP. It is binding for all euro area Member States, while other Member States will be bound once they adopt the euro or, upon their discretion, earlier and with the possibility to choose the provisions they wish to comply with (European Parliament and European Council, 2011).

The Fiscal Compact specifies the rules for curtailing public debt in case that the limit of 60 per cent of GDP is exceeded. ${ }^{5}$ It also requires that Member States converge towards country-specific MTOs with a limit of 0.5 per cent of GDP on structural deficits, also coined the 'golden rule' (Verhelst, 2012). This can be extended to 1 per cent for Eurozone countries with a debt ratio significantly below 60 per cent of GDP. Economists expect future MTOs to converge towards the 0.5 per cent benchmark, which should be integrated in Member State constitutions, because it would force Eurozone countries to have balanced budgets in good times and render the likelihood of more than 3 per cent deficits less likely in economic downturns (Verhelst, 2012). There is some flexibility, since the golden rule can be temporarily disregarded in exceptional circumstances. Nevertheless, the structural deficits enshrined in both the Six-Pack and the Fiscal Compact imply a high degree of enforcement and represent a further step in European Integration by imposing Eurozone-fiscal discipline. However, even economists are concerned about the stringency of the golden rule, since it 'risks obstructing public investments that address long-term challenges such as ageing and the shift towards a green economy. It seems therefore preferable that the implementation of the golden rule considers public investments. If not, Eurozone countries will, perhaps sensibly, be inclined to circumvent their golden rule' (Verhelst, 2012, p. 3). In the case of circumventing the 
norms laid down by the Fiscal Compact, the ECJ can impose financial sanctions of up to 0.1 per cent of GDP in case of non-compliance, which reinforces the corrective enforcement (European Central Bank (ECB), 2012, p. 83).

Another novelty is that Member States must report on their national debt issuance to the Commission and the Council. This entails the expectation to discuss ex ante 'all major policy reforms', which suggests that it is negotiable bi-laterally with each Member State, taking due account of circumstances. The FC strengthens the enforcement mechanism of the SGP, since all stages of the EDP should be implemented within a clearly defined time frame. When the Commission considers that an excessive deficit exists, this decision can only be overturned by RQMV. The Fiscal Compact thus strengthens the decision-making capacity of the Commission (compared with the SixPack) and reduces the political discretion of the EU Council because of RQMV. The measures for exiting an EDP and the timetable are negotiated between the Commission and the Member State, as was the case in the original SGP. Thus, there is some room for negotiation although the threat of bad credit ratings from international rating agencies culminating in a sovereign debt crisis may incite Member States to follow reform paths developed with the Commission more closely (see contributions in this issue; de la Porte and Natali, 2014).

The Fiscal Compact, focused on fiscal discipline, builds on the Six-Pack, but makes the aims with regard to structural deficits even more stringent. Surveillance is high as Member States must discuss major reforms with the European institutions before their adoption. Ultimately, it reduces Member States' room for manoeuvre with regard not only to fiscal consolidation, but also structural reforms, such as in health care, pensions and labour markets. Moreover, the Fiscal Compact requires Member States to include the country-specific MTOs in national binding law, preferably at constitutional level. The instrument represents yet another initiative layered onto an existing institutional framework, rather than revision, since none of the previous instruments are replaced.

\section{Two-Pack}

The Two-Pack, which came into force in May 2013, is a third initiative that has been layered onto the existent instruments governing the EMU (European Commission, 2013b). It specifies objectives in budgetary policy, together with high enforcement and surveillance mechanisms. ${ }^{6}$ Its novelty is to have introduced a common budgetary timeline and rules for all euro area countries. The Two-Pack has a significant impact on 'sovereign' budgets - the basis for policymaking - as it requires Member States to send their budget proposals first for approval to the Commission and the Eurogroup, before they are submitted to national parliaments.

The fact that national budgets, and thus details of (welfare) policy reforms, are the object of close scrutiny with strong potential for the EU to intervene in reform plans 
implies that euro area countries are now developing budgets in the shadow of EU surveillance. The Commission and the Eurogroup in their first assessment of Eurozone countries' Draft Budgetary Plans ${ }^{7}$ have concluded that only two countries were 'compliant', three were 'compliant without any margin for possible slippage', three were 'broadly compliant' with 'some deviation from the adjustment path towards the MTO', and five were in the category 'at the risk of non-compliance'. On this basis, recommendations were made to these countries. It is only in the case of 'particularly serious non-compliance' that the Commission may request a revision of the draft budgetary plan. It remains to be seen how effective enforcement will be and how precisely the Commission could require alterations in national budgets. Still, it represents much more interference in Member State budgets compared with before the crisis.

\section{Altering the Governance of the European Social Dimension since 2010}

In this section, we discuss how social policy aims and instruments per se have been altered in the wake of the crisis and what this signifies for the European Social dimension. The coordination of European social and labour market policy was coordinated in the EES and various OMCs that have been institutionalised in the Lisbon Strategy in 2000 with the aim to achieve high levels of employment in combination with high levels of social protection. Pre-crisis, EU influence on setting policy objectives was medium, while the surveillance and enforcement of measures were low because the Lisbon Strategy was governed by the OMC (de la Porte and Heins, 2014). The Lisbon Strategy has been replaced (an instance of revision from the perspective of institutional change) by Europe 2020 , with many of the same mechanisms, a few institutional innovations and a reinforcement of many aims, but with weak mechanisms of surveillance and enforcement.

\section{Europe 2020}

In June 2010, a new 10-year growth strategy coined 'Europe 2020' replaced the Lisbon Strategy as the main social and labour market policy instrument at European level (European Commission, 2010b). Like the new instruments governing EMU, Europe 2020 first insists on fiscal consolidation in the crisis context. Beyond that, it is designed to deliver growth, if possible, socially and environmentally sustainable growth, requiring immediate investments, but to pay off later in terms of economic growth, as well as social well-being and equality as well as a greener environment. However, this strategy is dependent on significant 
government expenditure that governments encumbered by a high public debt are hardly able to provide.

Europe 2020 is organised around five EU Headline Targets, which are supported by 10 'Integrated Guidelines' covering economic, environmental, employment and social issues, and seven 'flagship initiatives', the latter being novel institutional innovations. The policies adopted in these areas are to be reported in 'National Reform Programmes' (NRPs). Concerning the policy objectives, two of the Integrated Guidelines are devoted to employment policy, and one to social exclusion, while there are no targets or guidelines for social protection issues. The aim to increase labour market participation stands stronger than ever - the previous benchmark of an average overall employment rate of 70 per cent was raised to 75 per cent (European Commission, 2010b). The 'Agenda for new skills and jobs' is the flagship initiative that aims at supporting this aim, but also at ensuring workers are skilled and adaptable to the altering aims on the labour market. Concrete proposals of this agenda are to improve flexicurity, to equip the work force with appropriate skills for the modern labour market, to improve job quality and working conditions, and, finally, to improve job creation. Employment subsidies or targeted reductions of non-wage labour costs as well as the promotion of self-employment - arguably of precarious character in the context of a crisis are among the suggested measures for job creation (European Commission, 2010a). These policies are by and large the same as those developed under the preceding Lisbon Strategy (2000-2010).

The social aim consists of promoting social inclusion, intimately linked to increasing labour market participation, and combating poverty. Under Europe 2020 Member States have committed to 'lift at least 20 million people out of the risk of poverty and exclusion’ by 2020 (European Council, 2011). Member States have to specify their own national targets in this area. These targets are not very ambitious, which suggests a lack of real political will to take the EU target seriously (de la Porte and Weishaupt, 2013). Another flagship initiative - the 'European platform against poverty and social exclusion' - supports the social exclusion aim of the EU. The degree of EU involvement regarding the Europe 2020 objectives is low for poverty reduction, while it is medium for objectives such as activation and raising employment rates.

EU surveillance of Europe 2020 is medium, as it takes place ex-post as part of an iterative policy cycle, now coordinated in the European Semester. On the basis of the NRPs, CSRs are be made to Member States, suggesting policies to be adopted for reaching the broad policy aims delineated in Europe 2020. Enforcement of the CSRs is low as the adoption of the suggested measures is voluntary. Existing evidence on CSRs on employment policies shows that they have at times been sources of inspiration for reform (de la Porte and Jacobsson, 2012). However, overall impact is low, particularly under conditions of fiscal constraint and low growth. 


\section{The Euro-Plus Pact (EPP)}

The EPP, adopted in March 2011, is based on the OMC between the 17 Eurozone members and six other countries (Bulgaria, Denmark, Latvia, Lithuania, Poland and Romania). Aiming at better economic policy coordination, it focuses on competitiveness, employment and financial sustainability, including a structured discussion on tax policy issues. It is a new initiative that has been layered onto the existing EU institutional framework. The EPP specifies objectives that primarily fall in areas that are under the competence of the Member States including wage monitoring, labour market reforms, tax reforms, pensions, health care and social benefits, fiscal rules and banking regulations.

In labour market policy, some objectives touch upon core labour market issues, including decentralising wage-setting agreements as well as revising wage indexation mechanisms (Barnard, 2012). The EPP penetrates into sensitive national welfare state issues, specifying objectives to a high degree. It is integrated into the European Semester, where Member States should report on progress made towards the main aims: surveillance is medium through analysis of progress made to issues that are central in the EPP, alongside the assessment of progress made in other processes. The EPP is voluntary, using the OMC, and surveillance as well as enforcement is therefore as low as it is for Europe 2020. While each Member State has the discretion to select their own national measures to achieve the common goals, and to decide how far-reaching reforms should be, national commitments should be integrated in the NRPs that are central for Europe 2020 and Stability or Convergence Programmes in the framework of the SGP. The Commission then assesses implementation by Member States of 'EPP commitments' together with the assessment of other CSRs. Compared with the new institutional architecture around the EMU and even Europe 2020 with its headline targets and flagship initiatives, the EPP objectives are not likely to make headway via an OMC process, since they require domestic political commitment.

\section{Social Investment Package (SIP) and youth guarantee}

Social investment is a comprehensive paradigmatic approach that emphasises the need to invest in individuals and their skills throughout the life-course so that they can participate in the labour market and combine this with other priorities, such as care responsibilities (European Commission, 2013d). It implies investing in institutions for early childhood, schools, vocational training, upper tertiary education, activation and life-long learning (see Morel et al, 2012). At the same time, temporary leave from the labour market should be facilitated without fear of job loss. Social investment ideas build on the foundations of the universalist welfare state, which is designed to meet these aims (see Kvist in this issue). 
Social investment, especially since a 2013 Commission Communication on the topic, provides an overarching policy framework to coordinate policy developed in economic, labour market and social policy. Member States can receive CSRs in the area of social investment through Europe 2020 (European Commission, 2013d). What differentiates it from the social OMCs and the EES is that funding, especially from the ESF, is intended to be better integrated with the SIP for the 2014-2020 period (European Commission, 2014). However, the EES was also combined with European funding and even where funding was linked to the EES aims, such as in the central and eastern European countries, the overall impact was weak (de la Porte and Jacobsson, 2012). Policy objectives are defined to a medium degree, while enforcement and surveillance are both weak, although they are medium if co-funding is included in pursuing an aim under the SIP.

Parallel to the launching of the SIP, an initiative coined 'Youth Guarantee' was launched in April 2013 via a Council Recommendation, because of the concern about youth unemployment. It was another instrument layered onto the existing Europe 2020 framework. The guarantee aims to ensure that all young people under 25 get a goodquality, concrete offer within 4 months of them leaving formal education or becoming unemployed. This is a specific policy objective, and is coherent with the supply-side aims of monetarism and also with the main gist of social investment. The purpose of it is to avoid the inactivity trap among young people, particularly those not in education, employment or training, as this could have consequences for their future. The Youth Guarantee strengthens the aim to activate young people, which was part of the EES already from the mid-1990s. Member State progress in this area is reported in 'National Youth Implementation Plans' which have started to be reported in 2014. What is different compared with the EES that also focused on youth is that $€ 6$ billion have been reserved in the 'Youth Employment Initiative' for the implementation of the guarantee across Member States (co-funded with Member States). If the initiatives are co-funded, then surveillance and enforcement will be medium; otherwise, they are low.

\section{Assessing the Institutional Alterations of EMU and the European Social Dimension}

Altogether, the Six-Pack, the Fiscal Compact and the Two-Pack have incrementally, and in rapid succession, been grafted onto the existing institutional framework to achieve aims of fiscal consolidation and balanced budgets already present in the Maastricht Treaty. Although their overall aims are not novel, they represent a major leap forward in EMU integration because of new benchmarks requiring fiscal restraint, combined with high levels of surveillance and enforcement. Through these new instruments, especially the monitoring of Member State budgets as well as reporting on structural reforms, Member States are under pressure to curtail expenditure in health care, pensions, early childhood programmes and elderly care. The AGSs highlight the 
need to keep public expenditure growth below the rate of medium-term GDP trends and to correct macro-economic imbalances, to decrease account deficits as well as levels of indebtedness (European Commission, 2011, 2012a, 2013a, 2014). The necessary resources to facilitate investment in human capabilities and to facilitate participation of women on the labour market, key elements in a sustainable social investment strategy, may not be prioritised or could be under-resourced.

Europe 2020, the main instrument to foster the European Social Dimension, has aimed to address the social and other non-monetary aspects of EMU and the EU. However, Europe 2020 and the instruments grafted onto it, in particular the SIP, are developed under the monetarist paradigm. Thus, instruments addressing social consequences of the crisis, for example, the Youth Guarantee frame policy responses that lean on supply-side policies. This was the case before the crisis as well, but the instruments and aims for fiscal consolidation, structural reforms and structural deficits were not nearly as constraining, effectively allowing for legitimate diversity. Now, the possibilities for diversity have become more limited through the framework and aims around fiscal and budgetary constraint.

However, since the immediate effects of the crisis are receding, social aims that are not only at the service of EMU are taking shape. Member States are encouraged to introduce more open-ended contracts to replace existing temporary or precarious contracts in order to improve employment perspectives for new recruits and to flexibilise conditions for open-ended contracts in order to reduce rigidities on the labour market. Furthermore, there is a renewed emphasis on the need to develop childcare institutions in order to facilitate the entry of second earners onto the labour market (European Commission, 2014). However, the resources available from the EU are very limited, which means that Member States need first to have balanced budgets and healthy economies to be able to make such investments. One possible institutional alteration

Table 2: Analytical results: EU integration levels of instruments of fiscal and social governance

\begin{tabular}{llll}
\hline & Objectives & Surveillance & Enforcement \\
\hline Fiscal policy coordination (to optimise the functioning & of the Eurozone) & \\
SGP (pre-crisis) & High & Medium & Medium \\
Six-Pack & High & High & Medium \\
Fiscal Compact & High & High & High \\
Two-Pack & High & High & High \\
& & & \\
Social and labour market policy coordination (to address issues of economic growth as well as social & & \\
sustainability) & Medium & Low & Low \\
Lisbon Strategy (pre-crisis) & Medium & Medium & Low \\
Europe 2020 & High & Medium & Low \\
Euro-Plus-Pact & Medium & Low/Medium & Low/Medium \\
Social Investment Package and Youth Guarantee & if co-funding & if co-funding \\
& & \multicolumn{2}{c}{} \\
\hline
\end{tabular}


would be to consider such investments as productive in the institutional architecture around EMU, if Europe is to improve and to maintain its social model.

Table 2 below summarises our findings with regard to the typology on EU integration and involvement, which shows that since the crisis, the EU has been much more involved in fiscal policy, a core issue for welfare states, but via the framework created for governing the Eurozone. It also shows that while there have been multiple initiatives integrated into and layered onto Europe 2020, these are governed by relatively weak instruments and processes, thus affecting welfare state reform through voluntarism only.

\section{Conclusion}

Since 2010, multiple new instruments have been created in the EU that affect welfare reform to an unprecedented degree. First, new instruments and policies have been grafted onto the existing institutional architecture to enhance the coordination of fiscal policy. The new norms, such as structural deficit rules as well as stricter enforcement and ex-ante surveillance of Member State budgets can be seen as a logical consequence of having more integration in monetary policy. These new norms have a significant impact on welfare states, as tight budgetary criteria will make expansionary public spending difficult even in healthy economies, let alone in crisis-ridden countries. The new instruments were agreed in unusually rapid succession in the context of an ongoing Eurozone crisis, leading to considerable institutional change in the EMU architecture in a short period of time. The resultant institutional architecture holds Member States accountable to the EU ex-ante and ex-post with regard to their budgets and public expenditure, including social expenditure.

Europe 2020, the instrument designed to coordinate employment and social policy and further develop the European Social Model, is comparatively weak compared with the sharpened objectives, surveillance and enforcement mechanisms in EMU. Although fostering social investment is on top of the EU social policy agenda, the extremely strict fiscal discipline and balanced budget rules that are highly institutionalised risk undermining the implementation of Europe 2020 which is now framed by the social investment strategy.

In the current situation, what is needed in order to ensure a highly skilled labour force together with economic growth is social investment. This requires financing in the short-term in order to reap benefits in the long-term, such as, for example, alternative forms of taxation and co-funding from the ESF, although the effect of this is likely to be limited. The risks of missing the opportunity to develop a sustainable welfare state and to focus only on a limited supply-side and liberal agenda is particularly high in countries that are still struggling not only with the effects of the crisis, but also with lack of institutions geared to make social investment sustainable starting with institutions for early childhood education and care, through schools, 
higher education and life-long learning. Therefore, it is of utmost importance that EMU criteria and the new instruments developed for fiscal consolidation should be altered to take account of investments made in such institutions, if the social investment strategy is to be more than an unattainable ambition.

\section{Acknowledgements}

We would like to thank many colleagues who have commented on different drafts of this article, including Susana Borrás, Jochen Clasen, Nathalie Morel, Joakim Palme, Maria João Rodrigues and Marion Schmid-Drüner.

\section{About the Authors}

Caroline de la Porte is Associate Professor at the Department of Society and Globalisation, University of Roskilde. Her research interests are centred on the EU and comparative welfare state reform, particularly in the areas of social inclusion, labour market policy and pensions. Her current research focuses on alterations to EMU governance after the crisis, ECJ case law for atypical contracts as well as social investment. She is member of the board of the Network for European Social Policy Analysis and is co-chair of the research network European Integration and Global Political Economy under the auspices of the Council for European Studies. She has recently contributed to various projects on the crisis and EU social policy, in journals such as West European Politics and Perspectives on European Politics and Society.

Elke Heins is Lecturer in Social Policy at the University of Edinburgh. Her research mainly focuses on labour market and health policy in comparative and European perspective. Recent publications in peer-reviewed journals such as Socio-Economic Review, European Journal of Industrial Relations and Journal of Social Policy dealt with the concept of flexicurity, the involvement of trade unions and third sector organisations in welfare policy delivery and the privatisation of welfare services.

\section{Notes}

1 In the framework developed by Hacker (2004) each type of change is associated with the types of political dynamics (coalitions and veto players) underlying possible type of change. In this article, we merely use the concepts to assess and to illustrate what types of changes have taken place in the European economic and social governance processes, without considering the political dynamics behind it.

2 Through the AGS, the EU Spring Council in March issues guidance covering fiscal, macroeconomic structural reform and growth enhancement for national policies on the basis of QMV. The policy priorities decided in the AGS should be included in Member States' Stability or Convergence 
programmes (concerning monetary policy) devised within the SGP, and in National Reform Programmes concerning economic, employment and social policies devised within Europe 2020 that are to be submitted in April. Finally, the Commission proposes Country Specific Recommendations, which are then to be adopted/altered by the Council before the summer.

3 The legislation consists of these six parts: (i) strengthening surveillance of budgetary positions and coordination of economic policies, (ii) acceleration and clarification of the EDP through a Council regulation, (iii) enforcement of budgetary surveillance in the euro area through a regulation, (iv) definition of a budgetary framework of the MS through a Directive, (v) prevention and correction of macroeconomic imbalances through a regulation, (vi) enforcement of measures for correcting excessive macroeconomic imbalances in the euro area.

4 The Fiscal Compact was signed in March 2012 by all EU members except the United Kingdom and the Czech Republic and is the fiscal part of the Treaty on Stability, Coordination and Governance.

5 The difference between the actual ratio and SGP limit shall be reduced by an average rate of onetwentieth per year as a benchmark.

6 The Two-Pack consists of two regulations (based on Art 136 TFEU) complementing the Six-Pack in euro area countries to improve the transparency and coordination of Member States' budgetary planning and decision-making processes (European Commission, 2013b).

7 Applicable to those countries that are not under a macroeconomic adjustment programme.

\section{References}

Barbier, C. (2012) La prise d'autorité de la Banque centrale européenne et les dangers démocratiques de la nouvelle gouvernance économique dans l'Union européenne. In: B. de Witte, A. Heritier and A.H. Trechsel (eds.) The Euro Crisis and the State of European Democracy. Florence, Italy: European University Institute, pp. 212-241.

Barnard, C. (2012) The financial crisis and the euro plus pact: A labour lawyer's perspective. Industrial Law Journal 41(1): 98-114.

De Haan, J., Berger, H. and Jansen, D. (2004) Why has the stability and growth pact failed? International Finance 7(2): 235-260.

de la Porte, C. and Heins, E. (2014) Game change in EU social policy: Towards more European Integration. In: M.J. Rodrigues and E. Xiarchogiannopoulou (eds.) The Eurozone Crisis and the Transformation of EU Governance. Aldershot, UK: Ashgate.

de la Porte, C. and Jacobsson, K. (2012) Social investment or recommodification? Assessing the employment policies of the EU member states. In: N. Morel, B. Palier and J. Palme (eds.) Towards a Social Investment Welfare State? Ideas, Policies and Challenges. Bristol, UK: Policy Press, pp. 117-152.

de la Porte, C. and Natali, D. (2014) Altered Europeanisation of pension reform in the context of the great recession: Denmark and Italy compared. West European Politics 37(4): 732-749.

de la Porte, C. and Pochet, P. (2012) Why and how (still) study the OMC? Journal of European Social Policy 22(2): 336-349.

de la Porte, C. and Pochet, P. (2014) Boundaries of welfare between the EU and member states during the 'great recession'. Perspectives on European Politics and Society 15(3): 1-14.

de la Porte, C. and Weishaupt, T. (2013) The open method of co-ordination for social inclusion and social protection: Theoretical and empirical state-of-the-art. In: J. Garcés and I. Monsonís Paya (eds.) Sustainability and Transformation in European Social Policy. Brussels, Belgium: PIE-Peter Lang, pp. 41-60.

European Central Bank (ECB) (2012) A fiscal compact for a stronger economic and monetary union, ECB Monthly Bulletin, May: pp. 79-94. 
European Commission (2010a) An Agenda for New skills and Jobs: A European Contribution Towards Full Employment. Communication from the Commission to the European Parliament, the Council, the European Economic and Social Committee and the Committee of the Regions, COM(2010) 682 final Strasbourg, France: European Commission.

European Commission (2010b) Europe 2020. A strategy for smart, sustainable and inclusive growth. Brussels, Belgium: European Commission, http://ec.europa.eu/europe2020/index_en.htm, accessed 20 May 2013.

European Commission (2011) Annual Growth Survey 2012, COM (2011) 815 final.

European Commission (2012a) Annual Growth Survey 2013, Brussels, Belgium: European Commission, http://ec.europa.eu/europe2020/pdf/ags2013_en.pdf.

European Commission (2012b) Report from the Commission on the Alert Mechanism Report 2013, $\operatorname{COM}(2012) 751$ final.

European Commission (2013a) Annual Growth Survey 2014. COM(2013) 800 final. Brussels, Belgium 13 November.

European Commission (2013b) Beyond the six pack and two pack: Economic governance explained. Memo/13/318. Brussels, Belgium, 10 April, http://europa.eu/rapid/press-release_MEMO-13-318_en. htm, accessed 30 April 2013.

European Commission (2013c) Strengthening the Social Dimension of the Economic and Monetary Union, COM(2013) 690 provisoire, Brussels, Belgium: European Commission, http://ec.europa.eu/ commission_2010-2014/president/news/archives/2013/10/pdf/20131002_1-emu_en.pdf, accessed on 16 October 2013.

European Commission (2013d) Towards Social Investment for Growth and Cohesion - including implementing the European Social Fund 2014-2020 COM(2013)083 final, 20 February.

European Commission (2014) Policy Roadmap for the 2014 Implementation of the Social Investment Package. Brussels, Belgium: European Commission.

European Council (2011) Conclusions of the Presidency EUCO 10/11, 25 March, Annex I.

European Parliament and European Council (2011) Regulation (EU) No 1173/2011 of 16 November 2011, on the effective enforcement of budgetary surveillance in the euro area, Official Journal of the European Union, L306/1-7.

Hacker, J.S. (2004) Privatizing risk without privatising the welfare state: The hidden politics of social policy retrenchment in the United States. American Political Science Review 98(2): 243-260.

Hassenteufel, P., Delaye, S., Pierru, F., Robelet, M. and Serré, M. (2000) La libéralisation des systèmes de protection maladie européens. Convergence, européanisation et adaptations nationals, Politique Européenne 1(2): 29-48.

Jepsen, M. and Serrano Pascual, A. (2005) The European social model: An exercise in deconstruction. Journal of European Social Policy 15(3): 231-245.

Jessoula, M. (2012) Like in a Skinner Box: External Constraints and the Reform of Retirement Eligibility Rules in Italy, Working Paper-LPF 4/2012, Milan.

McNamara, K.R. (2005) Economic and monetary union: Innovation and challenges for the euro. In: H. Wallace, W. Wallace and M.A. Pollack (eds.) Policy-making in the European Union, 5th edn. Oxford: OUP, pp. 141-160.

Morel, N., Palier, B. and Palme, J. (eds.) (2012) Towards a Social Investment Welfare State? Ideas, Policies and Challenges. Bristol, UK: Policy Press.

Scharpf, F. (2002) The European social model. Journal of Common Market Studies 40(4): 645-670.

Scharpf, F. (2011) Monetary Union, Fiscal Crisis and the Preemption of Democracy. Cologne: Max Planck Institute for the Study of Societies. Discussion Paper 11/11, Cologne.

Van Aken, W. and Artige, L. (2013) Reverse majority voting in comparative perspective: Implications for fiscal governance in the EU. In: B. de Witte, A. Heritier and A.H. Trechsel (eds.) 
The Euro Crisis and the State of European Democracy. Florence, Italy: European University Institute, pp. 129-161.

Verhelst, S. (2012) Will the national 'golden rule' eclipse the EU fiscal norms?, http://www.voxeu.org/ article/what-will- golden-rule-mean-eurozone, accessed 26 June 2014.

Viebrock, E. and Clasen, J. (2009) Flexicurity and welfare reform. Socio-Economic Review 7(2): 305-331. 